\title{
O modelo de governança eleitoral brasileiro e a judicialização das regras político-eleitorais
}

\section{The brasilian electoral governance model and the judicialization of political-electoral rules}

\section{Caroline Bianca Graeff Alvaro Augusto de Borba Barreto}

\section{Resumo}

Este artigo tem por objetivo analisar como a judicialização das regras político-eleitorais é favorecida pelas características institucionais da Justiça Eleitoral e pelo modelo de governança eleitoral adotado em nosso país. Através de uma revisão bibliográfica sobre a judicialização da política e também sobre o modelo de governança eleitoral brasileiro, apontam-se alguns aspectos desta instituição que propiciam a judicialização político-eleitoral. Destacam-se a forma de composição do órgáo eleitoral e as suas competências, as quais abrangem tarefas de cunho administrativo que envolvem a organizaçáo das eleiçóes, de resolução de conflitos decorrentes da disputa eleitoral, mas também funçóes normativas (rule making) que delegam a esta justiça ampla margem de atuação no que tange a regulação das matérias eleitorais.

\section{Palavras-chave}

Judicialização Político-eleitoral; Modelo de Governança Eleitoral; Função Normativa.

\begin{abstract}
This article aims to analyze how the judicialization of political-electoral rules is favored by the institutional characteristics of the Electoral Justice and by the model of electoral governance adopted in our country. Through a bibliographical review of the judicialization of politics and also of the model of Brazilian electoral governance, some aspects of this institution that favor political-electoral judicialization are signaled. The composition of the electoral body and its competences, which include administrative tasks involving the organization of the elections, the resolution of disputes arising from the electoral contest, but also the rule making functions, delegate to the electoral body strong authority regarding the regulation of electoral matters.
\end{abstract}

\section{Keywords}

Political-Electoral Judicialization; Model of Electoral Governance; Normative Function. 


\section{Introdução}

Nos últimos anos tem-se visto a presença constante do Tribunal Superior Eleitoral (TSE) como regulador das regras político-eleitorais. Dentre os exemplos, pode-se citar a interferência do TSE em questóes como a determinação da verticalização das coligaçôes e da fidelidade partidária; a redefinição das regras para distribuição do fundo partidário; a redução do número de vereadores; ou, ainda, a aprovação da prestaçáo de contas como exigência para a emissão da certidão de quitação eleitoral.

Este artigo tem por objetivo analisar como a judicialização das regras políticoeleitorais é favorecida pelas características institucionais da Justiça Eleitoral e pelo modelo de governança eleitoral adotado no Brasil. Destacam-se a forma de escolha e seleção dos membros desta Justiça, os quais, em sua grande maioria, provêm da intersecção com membros de outros órgãos do judiciário, também o fato de o legislativo não participar desta escolha e do chefe do executivo ter apenas o papel de nomear os membros oriundos da advocacia. Além disso, este modelo de governança concentra na instituição tanto as tarefas de adjudicação dos conflitos (rule adjudication) e de aplicação das normas (rule application), quanto a função de formulação das regras (rule making), proporcionando uma crescente interferência do TSE como normatizador das regras eleitorais.

Para tanto, desenvolve-se uma revisão bibliográfica acerca da judicialização da política e das regras político-eleitorais e sobre o modelo de governança eleitoral brasileiro, destrinchando-se as características institucionais e as atribuiçóes desta Justiça especializada e em particular sua função normativa, para entáo concluir sobre a relação que tais atribuiçôes possuem com a crescente atuação do TSE como órgão judicializador da política.

\section{Judicialização da politica}

Essa expressáo passou a ser largamente utilizada no universo acadêmico há 20 anos, quando os pesquisadores Neal Tate e Torbjörn Vallinder organizaram um livro intitulado The global expansion of judicial power (1995). $\mathrm{Na}$ obra, além de contribuiçôes teóricas em torno da definição do conceito, são estudados os casos de países das tradiçóes do commom law e do civil law cujas experiências serviram de indício e de comprovação da existência da expansão global do poder judicial: Estados Unidos, Reino Unido, Austrália, Canadá, Alemanha, França, Itália, Holanda, Suécia, Israel, Malta, Rússia e outras ex-repúblicas soviéticas, Filipinas e Namíbia. 
Vallinder (1995, p. 13) conceitua “judicialização da política” como "a difusão de tomada de decisôes judiciais e de procedimentos típicos das cortes em arenas políticas onde não residiam anteriormente" ${ }^{1}$. Porém, há outros enunciados do conceito, a indicar diversos focos de estudos que podem ser relacionados ao assunto. Para Marchetti e Cortez (2009, p. 425), "o conceito de judicializaçáo significa, no limite, que o judiciário exerce poder sobre o processo político".

Nesse sentido, Vallinder (1995) se dedica a especificar duas acepçóes da expressão:

Assim, a judicialização da política pode significar tanto (1) a expansão da competência de tribunais ou de juízes em detrimento dos políticos e/ou dos administradores, ou seja, a transferência dos direitos de tomada de decisão do legislativo ou do executivo para os tribunais, ou, ainda, (2) a difusão de métodos de tomada de decisóes judiciais para fora da esfera de ação judicial propriamente dita. Resumindo, podemos dizer que a judicialização envolve essencialmente transformar algo em uma forma de processo judicial $^{2}$ (VALLINDER, 1995, p. 13).

Nessa perspectiva, Vallinder (1995) estabelece dois tipos judicialização. O primeiro, também chamado de from without (vindo de fora ou, simplesmente, de fora) se refere ao ponto 1 da citação, e ocorre quando o judiciário se incumbe do papel de revisor e de efetivador das açóes do executivo e do legislativo, comportando em suas competências a tomada de decisões políticas. Já o segundo, correspondente ao ponto 2 da citação acima, é from within (vinda de dentro, ou simplesmente, de dentro), o qual acontece quando há a transferência dos métodos judiciais de tomadas de decisóes para outras esferas de poderes, caso das Comissões Parlamentares de Inquérito (CPI), tribunais administrativos, agências reguladoras, conselhos, ouvidorias. Também se pode falar em "judicialização from within", quando os demais poderes introduzem em suas funçôes administrativas integrantes do judiciário ou

\footnotetext{
1 Tradução livre realizada pelos autores. No original: "to the infusion of judicial decision-making and courtlike procedures into political arenas where they did not previously reside".

${ }^{2}$ A formulaçáo literal, traduzida livremente pelos autores, é: "thus the judicialization of politics should normally mean either: (1) the expansion of the province of the courts or the judges at the expense of the politicians and/or the administrators, that is, the transfer of decision-making rights from the legislature, the cabinet, or the civil service to the courts or, at least, (2) the spread of judicial-making methods outside the judicial province proper. In summing up we might say that judicialization essencially involves turning something into a form of judicial process".
} 
métodos judiciais de trabalho, como ocorre na Suécia em que juízes deixam as cortes por alguns anos para exercer funçóes de Ministros no Executivo. Para Eisenberg (2002), no entanto, esta modalidade náo se trata propriamente de expansão do poder judicial, tomado como a capacidade de decidir em lugar de outros poderes, e sim da assimilaçáo do discurso e de procedimentos jurídicos pelos outros poderes.

O presente artigo trabalha com a "judicialização from without" - aliás, aquela mais comumente abordada pela bibliografia internacional. Entende-se que a “judicialização da política” pode ser considerada como o processo em que o Poder Judiciário expande sua competência, exercendo papéis que a priori não seriam incluídos em suas funçóes típicas, influenciando, dentre outras áreas de abrangência da sociedade, o processo político-eleitoral.

Tate (1995) enumera algumas características que seriam facilitadoras para o surgimento da judicialização da política em determinado Estado:

a) Democracia: um governo democrático seria característica necessária para o desenvolvimento da "judicialização da política”, embora não suficiente. Não haveria espaço para a expansão do judiciário em um estado autoritário, pois nenhum ditador aceitaria uma participação ativa de juízes independentes na criação de políticas públicas nem toleraria decisóes baseadas em regras e direitos processuais legalistas;

b) Separação de Poderes: o sistema de separação de poderes facilitaria a judicialização, pois, nesta estrutura de governo, o judiciário se estabelece como um poder independente e co-igual ao executivo e ao legislativo, dando-lhe autonomia institucional e liberdade para que seus membros possam tratar de questóes políticas, ainda que, formalmente, no sistema de separação de poderes a funçáo atribuída aos juízes abarcaria apenas a tarefa de interpretar, e não a de produzir leis.

Adotando os ensinamentos trazidos por Montesquieu, em sua obra "O Espírito das Leis" (1973), a teoria dos três poderes baseia-se no estabelecimento de autonomia e de limites para ambos, com o fim de evitar que haja em um único órgão o poder absoluto sobre todo Estado. Deste modo, cria-se o sistema de freios e de contrapesos, o qual estabelece a autonomia destes órgáos para a realização de suas funçóes, promovendo, no entanto, o exercício mútuo de controle entre os poderes.

Cumpre mencionar que cada um dos poderes exerce funçóes típicas de seus órgãos, mas também, de forma mais ponderada, funções atípicas. Pode-se exemplificar da seguinte maneira: a função típica do Poder Judiciário é julgar controvérsias, porém, ainda que pormenorizadamente, exerce funçóes típicas do executivo, ao administrar seus órgáos; e do legislativo, tanto internamente, ao realizar normas reguladoras do exercício de suas funçôes, como externamente, por meio das 
normatizaçóes realizadas pelos Tribunais, sendo estas denominadas de funçôes atípicas do judiciário.

Porém, a "teoria dos três poderes" foi formulada há mais de 250 anos e, ao longo desse tempo, profundas alteraçôes foram promovidas no modelo de Estado e, por isso, na própria teoria. Desse modo, o monopólio da lei não mais reside exclusivamente no Poder Legislativo, ao inverso, é compartilhado com o executivo e o judiciário, por meio do judicial review, fixado nos EUA logo após a formulação original de Montesquieu e hoje difundido por vários outros países - Brasil incluso. Assim, o judiciário, "boca que pronuncia as sentenças da lei", inerte e mero intérprete, deixou de ser realidade há muito tempo, caso tenha assim se apresentado em alguma oportunidade.

Vianna (2013, p. 207) assevera que o processo de "judicialização da política" "tem importado uma efetiva mutaçáo institucional na cena republicana na medida em que afeta as relaçóes entre os poderes executivo, legislativo e judiciário, e o cânon republicano quanto ao império da vontade da maioria". Entáo, a "judicialização da política" estaria transpondo para o judiciário as funçóes que deveriam ser compreendidas pelos representantes democraticamente eleitos para exercer tais competências, papéis do legislativo e do executivo;

c) Política de Direitos: estes direitos são pensados como aqueles individuais e políticos, na vertente do liberalismo clássico e da Declaração dos Direitos do Homem de 1948, mas também sociais. Assim, as constituiçôes deixaram de ser simplesmente um elenco de direitos individuais e da descrição da estrutura do Estado, e passaram a incluir uma série de direitos coletivos, que devem ser garantidos e preservados. A existência de direitos individuais e de proteção às minorias aparece para Tate (1995) como condição facilitadora para o surgimento da "judicialização da política" na medida em que esses direitos - que podem ser garantidos ou impostos sobre a vontade das maiorias por meio do judiciário - aumentam a importância das cortes que se tornaram os principais atores na efetivação destes direitos;

d) Utilização das cortes por grupos de interesses: a potencialidade dos tribunais em fazer cumprir suas decisóes faz com que grupos de interesses se utilizem das cortes como uma possibilidade concreta para alcançar seus objetivos sociais, econômicos ou políticos;

e) $\mathrm{O}$ uso das cortes pela oposição: a expansão da judicialização também se daria devido ao uso pela oposição dos Tribunais como meio de perseguir ou obstruir os interesses de governos ou grupos majoritários, opondo processos judiciais para 
reverter as iniciativas que não conseguiria derrotar através do processo ordinário majoritário;

f) Ineficácia das instituiçóes majoritárias: outro facilitador da expansão da judicialização seria a ineficácia das instituiçôes majoritárias em garantir os direitos ou em efetivar as políticas públicas previstas, o que levaria a busca por essa efetivaçáo através do judiciário;

g) Percepção das instituições elaboradoras de políticas: quando a população, os grupos de interesse e as instituiçóes sociais constatam uma imobilizaçáo das instituições majoritárias e ainda a crescente deflagração de corrupção nestas instituiçôes, acabam procurando no judiciário, que possui uma reputação de idoneidade e perícia de seus membros, a solução para problemas de ordem jurídica, colaborando assim para o desencadeamento da judicialização;

h) Delegação pelas instituiçôes majoritárias: a última condição facilitadora para a judicialização trazida por Tate (1995), seria a delegação das decisóes políticas para os tribunais, por parte das próprias instituiçóes majoritárias. Isto se daria devido ao custo político que a tomada de determinadas decisóes traz. Um dos exemplos mencionados diz respeito à legalização do aborto, questão que divide opinióes na sociedade e, consequentemente, um posicionamento político do legislativo ou do executivo teria o custo do desagrado a parte dos seus eleitores. Desta forma, a delegação de tais decisóes para as cortes judiciais exoneraria os Poderes Representativos de consequências eleitorais.

Como é possível perceber pelas características narradas acima, Tate e Vallinder (1995) não demonstram claramente como esses elementos estão associados ao advento do fenômeno. Eles se dedicam mais a listar uma série de regras institucionais ou de comportamentos, de curto e de longo prazo, que propiciam o advento da "judicialização da política", sem explicitarem como eles se relacionam entre si e com ao próprio fenômeno. $\mathrm{Na}$ mesma medida, não especificam quais são causas e quais são consequências, quais são motivaçôes institucionais e quais dependem da decisão e do engajamento dos atores, de modo a Carvalho (2004, p. 122) considerar que existe um "argumento tautológico por trás da definição da judicialização da política”.

Talvez por essas razōes a "judicialização da política" tenha subsidiado estudos tâo divergentes entre si, de modo a configurarem, de fato, diferentes acepçôes da expressão. Romanelli (2012, p. 15) anota que "a literatura disponível costuma tratar de forma indistinta origens institucionais (no arranjo jurídico das instituiçóes), fenômenos sociológicos (como reflexos do desencanto da democracia), políticos 
(como o enfraquecimento do legislativo) e jurídicos (como o aumento do acesso à justiça e a justiciabilidade dos direitos sociais)".

No Brasil, críticas semelhantes partiram de Maciel e Koerner (2002). Os autores pontuam, inicialmente, que a denominação se tornou de rápida circulação nos meios acadêmicos, desde que surgiu nos estudos pioneiros de Castro (1997), Teixeira $(2001)^{3}$ e Vianna et al. (1999), mas consideram que a expressão é utilizada de modo fluido por muitas investigaçôes, que a concebem a partir de distintas perspectivas teórico-analíticas e alcançam resultados igualmente díspares, às vezes contraditórias.

Entende-se que a judicializaçáo da política se trata da constatação de um fenômeno, o da intensificação do poder de atuação do judiciário, tornando-se assim, a descrição de um modus operandi observado no judiciário. Dessa forma, este conceito não deve ser entendido como ferramenta analítica que propicie a compreensão de conflitos ou interfaces resultantes da relação entre Direito e Justiça, sendo sim uma expressão descritiva que faz um diagnóstico do comportamento dos tribunais, descrevendo, portanto, o fenômeno de expansão do Poder Judiciário.

Para delinear e especificar o assunto tratado neste artigo é importante frisar que não se pretende exaurir todos os aspectos que influenciam a atuação da Justiça Eleitoral como judicializadora das regras político-eleitorais. Almeja-se analisar apenas como o arranjo institucional existente na Justiça Eleitoral brasileira e o modelo de governança eleitoral adotado no Brasil propiciam este fenômeno.

Dessa forma, não se pretende esgotar o assunto nem descartar outros elementos propiciadores da expansão da atuação da Justiça Eleitoral, como por exemplo, os fenômenos políticos e jurídicos levantados por Sadek (1995), que observa na instabilidade das leis eleitorais e nas dubiedades deixadas pelo legislador elementos que propiciam a judicialização político-eleitoral, ou aspectos de ordem sociológica segundo os quais há uma descrença nas instituiçóes democráticas pela população e pela própria corte eleitoral a qual entenderia sua a função de defender o interesse público e corrigir o processo eleitoral (FERRAZ JÚNIOR, 2008), tampouco a tese de que a Justiça Eleitoral estaria atuando como preenchedora das lacunas deixadas pelo poder legislador (MARCHETTI e CORTEZ, 2009), ou que esta Justiça

\footnotetext{
${ }^{3}$ O trabalho foi publicado como livro em 2001, mas é originário de uma dissertação de mestrado defendida em 1997.
} 
Especializada estaria apenas agindo como garantidora e efetivadora da democracia (TAYLOR, 2007; VIANNA, 2013).

Contudo, entende-se que a atuaçáo do Judiciário Eleitoral é "favorecida pela força institucional conferida pelo modelo de Governança que adotamos" (FERRAZ JÚNIOR, 2008, p. 209-210), tornando-se essencial compreender como este modelo de organização institucional propicia o fenômeno da judicialização político-eleitoral no Brasil.

\section{O modelo de governança eleitoral brasileiro}

A literatura internacional denomina "governança eleitoral" o "conjunto de regras e instituiçóes que definem a competição político-eleitoral" (FERRAZ JÚNIOR, 2008, p. 22). Conforme Mozaffar e Schedler (2002, p. 7), que formularam o enunciado do conceito, ele abrange "um grande número de atividades que cria e mantém o vasto arcabouço institucional no qual se realizam o voto e a competiçáo política" ${ }^{4}$.

Ela costuma ser distinguida em três níveis ou dimensões: formulação de regras (rule making), aplicação das regras (rule application) e adjudicação de regras (rule adjudication).

O rule making seria a escolha e a definição das regras básicas do jogo eleitoral. Nesse nível da governança eleitoral é que são determinados, por exemplo, a fórmula eleitoral, os distritos eleitorais, a magnitude das eleiçóes, as datas em que serão realizadas e outras questóes legais que permitam aos concorrentes a segurança de como o jogo será jogado. Aqui também são definidas algumas regras que pouca atenção recebem da literatura política, como as regras da (in)elegibilidade e da organizaçáo dos órgãos responsáveis pela administração das eleições (FERRAZ JÚNIOR, 2008, p. 23).

$\mathrm{O}$ rule application envolve a "implementaçáo e o gerenciamento do jogo eleitoral” (FERRAZ JÚNIOR, 2008, p. 23) e engloba procedimentos que: antecedem a votação, como o credenciamento dos eleitores e dos próprios competidores; perpassam a coleta dos votos; e se encerram com a contagem desses sufrágios, a publicação dos resultados e a diplomação dos eleitos. $\mathrm{O}$ rule adjudication,

\footnotetext{
${ }^{4}$ Texto original: "Electoral governance is the wider set of activities that creates and maintains the broad institutional framework in which voting and electoral competition take place". Tradução livre realizada pelos autores.
} 
por sua vez, envolve a solução dos litígios entre os competidores e ocorre antes, durante e depois da votação.

Como é possível perceber, o modelo de governança eleitoral brasileiro concentra essas atividades em um único órgão, chamado de Justiça Eleitoral. A legislação que a criou foi o Código Eleitoral de 1932, posteriormente abarcado pela Carta Magna de 1934. Desde então, todas as demais Constituiçóes brasileiras, com exceção da de 1937, trouxeram a Justiça Eleitoral estabelecida em seu corpo, a ela determinando a tarefa de conduzir as eleiçóes no País.

Assim, em substituição ao padrão anteriormente vigente no país, no qual executivo e legislativo concentravam a realização das eleiçóes (rule administration sob responsabilidade do primeiro; rule adjudication, do segundo), a Justiça Eleitoral brasileira foi criada com o intuito de moralizar as eleições, até então marcadas por fraudes, pelo voto a "cabresto" e pelo coronelismo, estabelecendo um órgão que tivesse função de dirimir os conflitos eleitorais, mas que também possuísse a tarefa de organização e de administração das eleiçôes. Tendo este órgão um caráter de neutralidade, no sentido de não possuir interesse direto no resultado da disputa eleitoral, diferentemente do legislativo e do executivo, ele poderia exercer de forma imparcial suas competências, evitando fraudes, condutas ilícitas, manipulação de votos, enfim, qualquer atitude que desvirtuasse o real resultado das eleiçóes.

Porém, para cumprir estes princípios, a Justiça Eleitoral foi constituída já em 1932, quando de sua criaçáo, com uma estrutura inusitada e distinta em comparaçáo às equivalentes internacionais já existentes ou adotadas posteriormente 5 .

A estrutura a que se faz referência compreende duas abrangências. A primeira se refere à estrutura orgânica da Justiça Eleitoral. Esta Justiça é composta pelo Tribunal Superior Eleitoral, que possui sete Ministros: três juízes dentre os Ministros do Supremo Tribunal Federal, dois juízes dentre os Ministros do Superior Tribunal de Justiça e dois juízes nomeados pelo Presidente da República dentre seis advogados indicados pelo STF; pelos Tribunais Regionais Eleitorais, compostos por dois juízes dentre os desembargadores do Tribunal de Justiça, dois juízes de Direito escolhidos pelo Tribunal de Justiça, de um juiz do Tribunal Regional Federal e por dois juízes nomeados pelo Presidente da República dentre seis advogados indicados pelo Tribunal de Justiça; os Juízes Eleitorais escolhidos dentre os Juízes de Direito da respectiva Comarca e pelas Juntas Eleitorais.

\footnotetext{
${ }^{5}$ Para mais informações sobre a criação da Justiça Eleitoral, ver Vale (2009) e Cadah (2012).
} 
Ferraz Júnior (2008) ao analisar cinco casos emblemáticos decididos pelo TSE - verticalização das coligaçóes, número de vereadores, cláusula de desempenho, fundo partidário e fidelidade partidária - cita alguns aspectos referentes à estrutura da instituição que são possibilitadores da judicialização no âmbito eleitoral:

Em primeiro lugar, vimos que o nosso modelo de governança eleitoral combina alguns elementos que tornaram possível a judicialização da competição política: concentração das atividades da governança em um único Organismo Eleitoral (OE), exclusão do Legislativo na indicação e seleção dos membros do OE, "regra da intersecçáo" com o Judiciário, principalmente com a Corte Constitucional, e elevação da governança eleitoral ao nível de controle constitucional (FERRAZ JÚNIOR, 2008, p. 203).

O fato de os membros do Organismo Eleitoral brasileiro serem advindos da intersecção com o judiciário, em sua quase absoluta maioria membros oriundos de outras instâncias do terceiro poder, e ainda o fato de os únicos membros externos serem advogados, ou seja, também do meio jurídico - e indicados pelo STF no caso do TSE e pelo Tribunal de Justiça nos casos dos TREs -, sem participaçáo do legislativo na indicação e seleção, evidencia o caráter judicializado da Justiça Especializada e propicia uma intensificação do poder de atuação do judiciário. Tal aspecto, como já mencionado, decorre do momento de criação da Justiça Eleitoral e da intenção de se inferir a uma instituição livre de interesses diretos na disputa eleitoral a tarefa de organização do pleito.

Da mesma maneira, a concentração de todas as atividades referentes à governança eleitoral (rule application, rule adjudication e rule making) nesta Justiça Especializada também decorre deste modelo instaurado com vistas a delegar toda a organização do pleito e demais tarefas relacionadas às eleiçóes a um órgáo dissociado das paixóes e dos interesses identificados nos demais poderes, diretamente vinculados à disputa e ao resultado que ela alcançar e, portanto, inaptos para promover as disputas eleitorais.

Com relação ao quarto aspecto levantado por Ferraz Júnior (2008), ponderase a questâo com um pouco mais de cautela. $\mathrm{O}$ autor aduz que a governança eleitoral estaria elevada ao nível de controle constitucional, afirmando que o TSE é um órgão do STF para matérias eleitorais, e faz essa afirmação sob o argumento de que a maior parte dos Ministros do TSE advém do STF e atuam concomitantemente nos dois tribunais superiores, além disso, o Presidente e Vice da Corte Eleitoral são escolhidos 
dentre os membros do Supremo e, por fim, diante do fato de que, quando o autor fez esta declaração, nenhuma decisão do TSE havia sido revogada pelo STF.

Contudo, deve-se flexibilizar esta afirmaçáo diante das divergências recentes ocorridas entre os dois órgãos, por exemplo, em relação à aplicação da Ficha Limpa, quando o STF definiu que ela produziria efeitos somente a partir de 2012, enquanto o TSE havia decidido que ocorreria imediatamente (em 2010, portanto), ou no caso da alteraçáo do tamanho das bancadas dos estados, quando o Congresso editou o Decreto Legislativo 424/13 que suspendeu a Resolução do TSE sobre a questão, e o STF, ao analisar a validade do Decreto, decidiu em favor dos interesses do Congresso. Isto demonstra que nem sempre (ou mais recentemente) os dois órgãos corroboram seus entendimentos e que o TSE não pode ser considerado de fato um órgão do STF para matérias eleitorais, como defende Ferraz Júnior (2008).

A segunda abrangência da estrutura institucional que infere diretamente na judicialização político-eleitoral é aquela referente às atribuiçôes, funções, prerrogativas ou aos também chamados "poderes" da Justiça Eleitoral. Como sintetiza Vale (2009), a Justiça Eleitoral assumiu, desde a sua criação, quatro funçôes bastante claras: jurisdicional, administrativa, consultiva e normativa.

Administrar o processo eleitoral é a principal atividade da Justiça Eleitoral ou, pelo menos, aquela a que ela mais se dedica. Jardim (1998, p. 40) anota: "embora montada em modelo tipicamente judiciário - estrutura, forma, pessoal, vestes talares e jargão judiciário, sua tarefa é essencialmente administrativa, e só eventualmente jurisdicional". De modo convergente, Coneglian (2003, p. 58) pondera: "enquanto todas as atividades fins de todos os órgãos da Justiça são julgar, ou exercer a jurisdição, a atividade fim da Justiça Eleitoral é realizar as eleições. Daí que a Justiça Eleitoral é o Poder Executivo das eleiçôes".

Porém, as atividades que constituem as funçóes mais importantes para o presente estudo são as demais, a começar pelo chamado poder regulamentar ou normativo. A legislação eleitoral, desde o primeiro Código de 1932, no art. 14,5, prevê a competência normativa desta Justiça Especializada, pois é determinado que a ela cabe fixar normas uniformes para aplicação das leis e regulamentos eleitorais, expedindo instruçôes que entenda necessárias (BRASIL, 1932). O atual Código Eleitoral (Lei 4.737/65), da mesma maneira, traz de forma expressa este caráter normativo: "Art. 23 - Compete, ainda, privativamente, ao Tribunal Superior: [...] IX - expedir as instruções que julgar convenientes à execução deste Código" (BRASIL, 1965). A lei orgânica dos Partidos Políticos (Lei 9.096, art. 61) e a Lei das eleiçôes 
(Lei 9.504, art. 105) também trouxeram a previsão da expedição das instruçóes necessárias à sua fiel execução 6 .

O poder normativo da Justiça Eleitoral é entendido como "a prerrogativa de interpretar o ordenamento jurídico-eleitoral, de estabelecer o alcance e o de definir o sentido da vontade normativa proclamada pelo Estado em matéria eleitoral" (PINTO, 2008, p. 114). O entendimento jurisprudencial do TSE é de que "essa competência não atinge apenas o poder de regulamentar a lei, [...] [também o] de "emprestar-lhe o sentido que a compatibilize no qual se insere" (LIMA, 2011, p. 78). Assim, esta função normativa tem o condáo de auxiliar a Justiça Eleitoral, pois a ela atribui o poder de adequar legislaçôes amplas aos casos concretos, alcançando as necessidades sociais, além de viabilizar determinados atos necessários para o correto transcorrer das eleições.

Esta função é manifesta por meio de resoluçôes que possuem força de lei ordinária, tomadas como atos normativos com as características da impessoalidade, generalidade e abstração, integrando, juntamente com as leis, a legislação eleitoral (PINTO, 2008).

Cumpre diferenciar a função normativa da Justiça Eleitoral, da função legislativa:

[...] função legislativa, que pode ser definida como aquela de emanação de prescriçôes primárias, geralmente, mas não necessariamente, com conteúdo normativo, feita por intermédio de lei formal. A distinção entre as funções normativa e legislativa se dá pelo grau de abstração e generalidade que as suas respectivas prescriçôes apresentam, bem como pela forma que surgem no ordenamento jurídico. Por conseguinte, a função normativa não é exclusiva do Poder Legislativo (a legislativa sim), podendo ser também exercida por outros órgáos (Executivo ou Judiciário), desde que prevista a atribuição na Constituição Federal ou em lei em seu sentido formal (PINTO, 2008, p. 93).

É possível registrar polêmica nos meios jurídicos acerca da prerrogativa normativa da Justiça Eleitoral, a qual cresce em intensidade quando, no entender dos críticos, esta exacerba o exercício de tal função.

\footnotetext{
${ }^{6}$ Também incluíam tal prerrogativa as leis emitidas antes do advento da chamada "Lei das eleiçóes" e que disciplinavam cada processo eleitoral em particular. Almeida Neto (2013) ainda arrola o art. 27 da lei 6.091/74, que dispóe a respeito do fornecimento de transporte a eleitores da zona rural em dia de votação, e o art. 18 da lei 6.996/82, que dispóe acerca da utilização eletrônica de dados.
} 
Araújo (2007) destaca que o texto constitucional estabeleceu que só o Presidente da República tem o poder de expedir normas regulamentadoras para a fiel execução das leis federais e o fez sem distinguir entre as normas comuns e as eleitorais. Logo, em tese, apenas o Presidente teria essa atribuição, e não a Justiça Eleitoral. De fato, em oposiçáo ao previsto na Constituição Federal, encontra-se o Código Eleitoral vigente (Lei 4.737/65) [e que foi recepcionado como Lei Complementar pela Constituição de 1988 em tudo aquilo que não a contrarie], que disciplina a competência privativa do Tribunal Superior Eleitoral.

Salgado (2010, p. 290) pondera que se admitida a atuação do TSE por meio de resoluçôes (inobstante sua inconstitucionalidade), estas devem "se subordinar à noção de função regulamentar de maneira estrita: aquela em que não há espaço para discricionariedade qualquer, mas apenas se deve desdobrar, especificar o que a lei determina de modo genérico".

Muitas investigaçôes dedicadas ao estudo de decisôes recentes da Justiça Eleitoral afirmam o entendimento de que o TSE náo tem cumprido essas exigências ao expedir resoluçóes ${ }^{7}$. Como sintetiza Lima (2011), elas têm sido utilizadas para formular conteúdo não previsto em lei ou incompatível com as normas legais e/ou expandir o sentido atribuído pela lei, de modo a desempenhar a atividade legislativa junto e às vezes em lugar do parlamento. Mas esta não é uma tendência recente, Vale (2009) identificou ao longo da história da Justiça Eleitoral que normas não previstas em lei foram criadas por meio de resolução - como é o caso da urna eletrônica -, sem contar as decisóes claramente contrárias ao texto legal então vigente, razão pela qual o TSE se torna um "poderoso legislador", como afirma a autora (VALE, 2009, p. 93).

$\mathrm{E}$, como não poderia deixar de ser, vozes defendem que, no exercício do poder normativo, a Justiça Eleitoral pode avançar e ser criadora em relação à norma legal vigente, sob o argumento primordial de que esta ação é justificada se for para garantir a lisura do pleito, assim como "estimulada" pelo teor do Direito Eleitoral. É o que sustenta Delgado, antes mesmo de a Justiça Eleitoral ter passado a adotar uma postura mais ativista:

\footnotetext{
${ }^{7}$ A considerar apenas estudos acadêmicos, das áreas de Ciência Política ou Direito, podem ser citados: Araújo (2007), Ferraz Júnior (2008), Garrido et al. (2008), Pinto (2008), Lamanauskas (2009), Marchetti e Cortez (2009), Salgado (2010), Maia (2010), Magalhães (2010), Soares, (2010), Lima (2011), Zauli (2011), Fantinel (2014), Nunes Júnior (2014) e Lopes (2015).
} 
É fundamental que a Justiça Eleitoral detecte a carência do direito legislado em se adaptar e de acompanhar as mutabilidades enfrentadas pelos agentes políticos em suas relaçôes com o poder e com a sociedade, suprindo, pela evolução de sua jurisprudência e pela competência normativa, embora limitada, que o sistema lhe outorga. [...] O nosso apego às ideias tradicionais leva-nos ao cultivo do princípio de que o objetivo primordial do regulamento é o de complementar a lei, explicando, unicamente o seu raio de ação. Ocorre que, por ter avançado em seu prestígio como norma reguladora, concebe-se, hoje, o de ter recebido uma característica de cunho supletivo e criador, desde que não resulte, a sua aplicaçáo, em se tornar incompatível com a norma positivada (DELGADO, 1995, p. 114-115).

É possível distinguir, ainda, a capacidade que tem a Justiça Eleitoral de responder a consultas formuladas e exercer a chamada função consultiva. Assim como no caso do poder normativo, ela figura no Código Eleitoral de 1965, no art. 23, o qual prevê a competência da Justiça para "responder, sobre matéria eleitoral, às consultas que lhe forem feitas em tese por autoridade com jurisdição, federal ou órgão nacional de partido político" (BRASIL, 1965) ${ }^{8}$.

As consultas são definidas como um "tipo de processo em que o Tribunal Superior Eleitoral e os Tribunais Regionais Eleitorais respondem a questionamentos formulados, em tese, por pessoas legitimadas sobre matéria eleitoral" (BRASIL, 2014) $)^{9}$. No dizer de Ferraz Júnior (2008, p. 46), “a consulta é, portanto, um instrumento administrativo que visa sanar dúvidas sobre matéria eleitoral”.

Vários autores procuram justificar a existência dessa função. Para Jardim (1998), a celeridade do processo eleitoral traz a necessidade de reduzirem-se os conflitos e os litígios e a conveniência de previsibilidade legal. Na opinião de Gomes (1998), ela é pedagógica e resulta que todos os partícipes do processo eleitoral possam cumprir com maior certeza os postulados legais. Conforme Machado (2013, p. 282), "as consultas muitas vezes funcionam como esclarecimentos prévios sobre as regras do jogo, o que contribui para a preservação da legitimidade e da estabilidade do sistema político-eleitoral”.

Pinto (2008) lembra que a resposta à consulta não envolve propriamente decisão, não tem caráter normativo ou jurisdicional e, por isso, não oferece garantia de que, frente ao caso concreto, será confirmada.

\footnotetext{
${ }^{8}$ Os TREs também têm esta competência, conforme o art. 30, VIII do Código Eleitoral.
} 


\begin{abstract}
Para alguns juristas, por não envolverem julgamento de litígio eleitoral, mas simples esclarecimento de dúvida suscitada pelo consulente, as respostas às consultas formuladas à Justiça Eleitoral expressam, apenas, a opiniấo da maioria da composição da Corte sobre determinada questão, em um momento determinado, delas não resultando nenhum comando significativo. [...] Não se trata de decisão sobre um direito contestado, mas de mera resposta, expressando a opinião do Tribunal consultado, e que, naturalmente, não exclui reconsideração. Por conseguinte, a resposta da consulta náo constitui coisa julgada, permitindo, ao contrário, renovação do questionamento (PINTO, 2008, p. 133).
\end{abstract}

A Justiça Eleitoral, portanto, tem competência distintiva em relação aos demais ramos do judiciário, que abrange a elaboração de resoluçóes, pelas quais o TSE expede os regulamentos que esclarecem a legislação ou definem determinada prática ou ato eleitoral e correspondem ao poder normativo; a resposta às consultas formuladas (funçáo consultiva) por partido político, TREs ou autoridades legitimadas a tal; bem como veicula decisóes dos litígios ou contenciosos judiciais nos quais suas determinaçóes emanam um entendimento da Corte que gere regulamento erga omnes.

Esta prerrogativa da Justiça Eleitoral, existente desde sua criaçáo, propicia a esta Instituição uma imersão em áreas próprias da função legiferante, e facilita a judicialização das regras político-eleitorais no momento em que abre espaço para uma interpretação e até uma criação normativa pela Justiça, com o fim de garantir o bom andamento do pleito e um processo eleitoral idôneo. Em outras palavras, a Justiça Eleitoral está legalmente autorizada a regulamentar a norma eleitoral, o que implica ampla margem de ação, podendo operar em nome da garantia da lisura e do bom andamento do pleito, fixando um determinado sentido às regras eleitorais (quando elas existem) ou criando-as (quando inexistentes).

Desta forma, diante dos aspectos institucionais aqui arrolados - a intersecção com o judiciário na composição da Justiça Eleitoral sem participação do legislativo na indicação e seleçáo; a concentração de todas as atividades referentes à governança eleitoral (rule application, rule adjudication e rule making) nesta Justiça; e a sua prerrogativa de normatizar o pleito - pode-se concordar com a ponderação de Ferraz Júnior (2008), segundo o qual o modelo de governança eleitoral brasileiro - a Justiça Eleitoral - é, desde a sua criação, "judicializado", ou seja, constituído a partir do judiciário e no qual este tem papel decisivo, extensível ao rule making. 
114 | Caroline Bianca Graeff e Alvaro Augusto de Borba Barreto

[...] a persistência desse modelo ao longo da consolidação democrática tem produzido a judicialização da competição político-partidária e que, além disso, tem possibilitado o avanço do Judiciário em atividades da governança eleitoral típicas do Legislativo, como a produção das regras do jogo competitivo (rule making) (FERRAZ JÚNIOR, 2008, p. 39).

Neste sentido, a intervenção do TSE nas regras eleitorais, que pode ser verificada por meio de uma série de episódios recentes - como a determinação da verticalização das coligações e da fidelidade partidária; a redefinição das regras para distribuição do Fundo Partidário; a redução do número de vereadores; a aprovação da prestação de contas como exigência para a emissão da Certidão de Quitação Eleitoral -, não é uma situação propriamente nova ou inédita, e sim a intensificação de uma prerrogativa institucional que a Justiça Eleitoral sempre teve.

\section{Conclusão}

Este trabalho pretendeu demonstrar que a judicialização político-eleitoral possui relaçáo direta com o modelo institucional de governança eleitoral adotado no Brasil. Observou-se que a judicialização da política se trata da constataçáo do fenômeno da intensificação do poder de atuação do judiciário, podendo ser considerado um diagnóstico do comportamento dos tribunais, o qual se observa presente na Justiça Eleitoral brasileira.

Também se analisou como a Justiça Eleitoral possui características presentes desde sua criação, as quais propiciam uma maior atuação deste órgáo diante das questôes político-eleitorais. Destacaram-se os aspectos institucionais referentes à composição da Justiça Eleitoral que é formada através da intersecção com o judiciário sem participação do legislativo na indicação e seleção dos membros da instituição, ou seja, é um organismo eleitoral judicializado desde o seu princípio, no sentido de ser constituído a partir do judiciário.

Ainda, observou-se que a concentração de todas as atividades referentes à governança eleitoral (rule application, rule adjudication e rule making) em um só órgão, a Justiça Eleitoral, delega a esta Justiça um enorme poder de atuação no âmbito eleitoral. Da mesma forma, a prerrogativa de normatizar o pleito, legalmente atribuída a esta Justiça que possui dentre suas funçóes o rule making, propicia a sua intensa atuação na interpretação e na criação do regramento eleitoral. 
Caroline Bianca Graeff é Doutoranda em Ciência Política na Universidade Federal de Pelotas. E-mail: carolinegraeff@gmail.com.

- Alvaro Augusto de Borba Barreto é Doutor em História pela Pontifícia Universidade Católica do Rio Grande do Sul. Professor do PPG em Ciência Política da Universidade Federal de Pelotas. Email: albarret.sul@terra.com.br.

\section{Referências}

ALMEIDA NETO, Manoel Carlos de. A Função administrativa da Justiça Eleitoral brasileira. In: CAGGIANO, Monica Hermann Salem (Coord.). Direito Eleitoral em debate - estudos em homenagem a Cláudio Lembo. São Paulo: Saraiva, 2013, p. 242-266.

ARAUJO, Rosa Maria Felipe. O Princípio da separação de poderes e a competência normativa do Tribunal Superior Eleitoral. 2007. 103 f. Dissertação (Mestrado em Direito Constitucional). Programa de Pós-Graduação stricto sensu em Direito Constitucional. Universidade de Fortaleza, Fortaleza, 2007.

BRASIL. Constituição (1988). Constituição da República Federativa do Brasil. Texto constitucional promulgado em 5 de outubro de 1988, com as alteraçôes adotadas pelas Emendas Constitucionais nos 1/1992 a 76/2013, pelo Decreto Legislativo no 186/2008 e pelas Emendas Constitucionais de Revisão no ${ }^{\circ} 1$ a 6/1994. 40.ed. com índice. Brasília: Centro de Documentação e Informação (CEDI), 2013. 464 p. Disponível em: < http://www2.camara.leg.br/atividadelegislativa/legislacao/Constituicoes_Brasileiras/constituicao1988.html >. Acesso em: 10 jun. 2014.

BRASIL. Lei 9.096, de 19 set. 1995. Disponível em: <http://www.planalto.gov.br/ccivil_03/leis/L9096.htm>. Acesso em: 15 jul. 2015.

BRASIL. Lei 9.504, de 30 set. 1997 (Estabelece normas para as eleiçóes). Disponível em: <http://www.planalto.gov.br/ccivil_03/leis/19504.htm>. Acesso em: 15 jul. 2015.

BRASIL. Lei 4.737, de 15 jul. 1965 (Código Eleitoral). Disponível em: <http://www.planalto.gov.br/ccivil_03/leis/14737.htm>. Acesso em: 24 jul. 2014.

BRASIL. Código Eleitoral de 1932. Disponível em: <http://legis.senado.gov.br/legislacao/ListaPublicacoes.action?id=33626>. Acesso em: 24 jul. 2014.

BRASIL. TSE. Glossário Eleitoral. Consulta Disponível em: <http://www.tse.jus.br/eleitor/glossario/termos-iniciados-com-a-letra-c\#consulta>. Acesso em: 22 jul. 2014.

CADAH, Lucas Queija. Instituiçôes eleitorais e competição politica - a criação da Justiça Eleitoral no Brasil. 2012. 81 f. Dissertação (Mestrado em Ciência Política). Programa de Pós-Graduação em Ciência Política. Universidade de São Paulo. São Paulo, 2012. 
CARVALHO, Ernani Rodrigues. Em busca da Judicialização da Política no Brasil: apontamentos para uma nova abordagem. Revista de Sociologia e Politica, Curitiba, n. 23, nov. 2004, p. 115-126.

CASTRO, Marcos Faro. O Supremo Tribunal Federal e a Judicialização da Política. Revista Brasileira de Ciências Sociais, São Paulo, v. 12, n. 34, p. 147-156, 1997.

CONEGLIAN, Olivar. A Justiça Eleitoral: O Poder Executivo das Eleiçôes, uma Justiça diferente. In: TEIXEIRA, S. de F. (Coord.). Direito eleitoral contemporâneo: doutrina e jurisprudência. Belo Horizonte: Del Rey, 2003. p. 57- 75.

DELGADO, José Augusto. A Contribuição da Justiça Eleitoral para o aperfeiçoamento da defesa da democracia. Revista de Informaçâo Legislativa, Brasília, a. 32, n. 127, p. 109-118, jul.-set. 1995.

EISENBERG, José. Pragmatismo, direito reflexivo e judicialização da política. In: VIANNA, Luiz Werneck (Org.). A Democracia e os três poderes no Brasil. Belo Horizonte; Rio de Janeiro: UFMG; IUPERJ; FAPERJ, 2002. p. 43-61.

FANTINEL, Aleksandra Ramos. Judicialização da política: o processo político-eleitoral e fidelidade partidária no Brasil (1988-2008). 2014, 72 f. Dissertação (Mestrado em Ciência Política). Programa de Pós-Graduação em Ciência Política. Universidade Federal do Rio Grande do Sul, Porto Alegre, 2014.

FERRAZ JÚNIOR, Vitor Emanuel Marchetti. Poder judiciário e competição política no Brasil: uma análise das decisóes do TSE e do STF sobre as regras eleitorais. 2008. 233 f. Tese (Doutorado em Ciências Sociais). Programa de Estudos Pós-Graduados em Ciências Sociais. Pontifícia Universidade Católica de São Paulo, São Paulo, 2008.

GARRIDO, Alexandre; GAMA, Fernando; RIBAS, José; NEUENSCHWANDER, Juliana; CAMARGO, Margarida; TUCHINER, Noel. A Função legislativa do Supremo Tribunal Federal e os partidos políticos. Revista Jurídica Faculdade Nacional de Direito UFRJ, Rio de Janeiro, n. 3, 2008, p. 35-77.

GOMES, Suzana de Camargo. A Justiça Eleitoral e sua competência. São Paulo: Revista dos Tribunais, 1998.

JARDIM, Torquato. Direito Eleitoral positivo. Brasília: Brasília Jurídica, 1998.

LAMANAUSKAS, Milton Fernando. A Jurisprudência eleitoral e seus reflexos no Estado Democrático de Direito. 2009. 285 f. Dissertação (Mestrado em Direito). Programa de Pós-Graduação em Ciência Política. Universidade de São Paulo, São Paulo, 2009.

LIMA, Sídia Maria Porto. O Ativismo judicial e o Judiciário eleitoral: um estudo da atividade legislativa do Tribunal Superior Eleitoral. 2011. 198 f. Tese (Doutorado em Ciência Política). Programa de Pós-Graduação em Ciência Política. Universidade Federal de Pernambuco, Recife, 2011.

LOPES, Ana Paula de Almeida. Poder judiciário e democracia: uma análise do impacto da intervenção judicial nas regras de competição política de 2002 a 2010. 2015, 243 f. Tese (Doutorado em Ciência Política). Programa de Pós-Graduação em Ciência Política. Universidade Federal do Rio Grande do Sul, Porto Alegre, 2015.

MACHADO, Marcelo Passamani. A Justiça Eleitoral. In: CAGGIANO, Mônica Herman S. (Coord.). Direito Eleitoral em debate - estudos em homenagem a Cláudio Lembo. São Paulo: Saraiva, 2013, p. 267-293.

MACIEL, Débora Alves; KOERNER, Andrei. Sentidos da Judicialização da política: duas análises. Lua Nova, São Paulo, n. 57, p. 113-133, 2002. 
MAGALHÁES, Flávia Cristina Mascarenhas. A Judicialização da politica e o direito eleitoral brasileiro no periodo 2002-2008. Brasília: Senado Federal, 2010.

MAIA, Clarissa Fonseca. O Ativismo judicial no âmbito da Justiça Eleitoral. 2010. 152 f. Dissertação (Mestrado em Direito Constitucional). Programa de. Universidade de Fortaleza, Fortaleza, 2010.

MARCHETTI, Vitor; CORTEZ, Rafael. A Judicialização da competição política: o TSE e as coligações eleitorais. Opinião Pública, Campinas, v. 15, n. 2, p. 422-450, nov. 2009.

MONTESQUIEU. O Espirito das Leis. São Paulo: Abril Cultural, 1973.

MOZAFFAR, Shaheen; SCHEDLER, Andreas. The Comparative study of electoral governance Introduction. International Political Science Review, v. 23, n. 1, p. 5-27, 2002.

NUNES JUNIOR, Amandino Teixeira. A Judicialização da política no brasil: análise das decisóes do TSE e do STF sobre verticalizaçáo dascoligações e fidelidade partidária. 2014, 199 f. Tese (Doutorado em Ciência Política). Programa de Pós-Graduação em Ciência Política. Universidade de Brasília, Brasília, 2014.

PINTO, Emanuel Roberto Girão de Castro. O Poder normativo da Justiça Eleitoral. 2008, $191 \mathrm{f}$. Dissertação (Mestrado em Direito). Programa de Pós-Graduação em Direito. Universidade Federal do Ceará, Fortaleza, 2008.

ROMANELLI, Sandro Luis Tomás Ballande. A Judicialização da política como meio de participação democrática - uma abordagem teórica para a legitimidade da jurisdição constitucional brasileira. 2012, 128 f. Dissertação (Mestrado em Direito). Programa de Pós-Graduação em Direito. Universidade Federal do Paraná, Curitiba, 2012.

SADEK, Maria Tereza. A Justiça Eleitoral e a Consolidação da Democracia no Brasil. São Paulo: Konrad Adenauer, 1995.

SALGADO, Eneida Desirée. Princípios constitucionais estruturantes do Direito Eleitoral. 2010, $345 \mathrm{f}$. Tese (Doutorado em Direito). Programa de Pós-Graduação em Direito. Universidade Federal do Paraná, Curitiba, 2010.

SOARES, José de Ribamar Barreiros. Ativismo Judicial no Brasil: o STF como arena de deliberação política. 2010, 193 f. Tese (Doutorado em Ciência Política). Instituto de Estudos Sociais e Políticos, Universidade Estadual do Rio de Janeiro, Rio de Janeiro, 2010.

TATE, C. Neal; VALLINDER, Torbjörn. The Global expansion of Judicial power. Nova York: New York University Press, 1995.

TATE, C. Neal. Why the expansion of judicial Power? In: TATE, C. Neal; VALLINDER, Torbjorn (Orgs.). The Global expansion of judicial power. Nova York: New York University Press, 1995, p. 2738.

TAYLOR, Matthew M. O Judiciário e as políticas públicas no Brasil. Dados, Rio de Janeiro, v. 50, n. 2, 2007, p. 229-257.

TEIXEIRA, Ariosto. Decisão liminar: a judicialização da política no Brasil. Brasília: Plano, 2001.

VALE, Teresa Cristina de Souza Cardoso. Justiça Eleitoral e judicialização da política: um estudo através da história. 2009. 233 f. Tese (Doutorado em Ciência Política). Instituto Universitário de Pesquisa do Rio de Janeiro, Rio de Janeiro, 2009.

VALLINDER, Torbjörn. When the courts go marching in. In: TATE, C. Neal; VALLINDER, Torbjörn. The Global expansion of Judicial power. Nova York: New York University Press, 1995, p. $13-26$. 
118 | Caroline Bianca Graeff e Alvaro Augusto de Borba Barreto

VIANNA, Luiz Werneck. A Judicialização da Política. In: AVRITZER, Leonardo et al. Dimensóes políticas da justiça. Rio de Janeiro: Civilização Brasileira, 2013.

VIANNA, Luiz Werneck; MELO, Manuel Palacios Cunha; CARVALHO, Maria Alice Rezende de .A Judicialização da política e das relaçóes sociais no Brasil. Rio de Janeiro: Revan, 1999.

ZAULI, Eduardo Meira. Justiça eleitoral e judicialização das eleiçôes no Brasil. Revista Brasileira de Estudos Políticos, Belo Horizonte, n. 102, p. 255-289, jan.-jun. 2011.

Texto recebido em 06 de dezembro de 2016. Aprovado em 25 de março de 2017. 